\title{
Anti-trypanosomal activity of doubly modified salinomycin derivatives
}

Michat Antoszczak a, ${ }^{\text {a }}$, Dietmar Steverding ${ }^{b}$, Michat Sulik ${ }^{a}$, Jan Janczak ${ }^{c}$, Adam Huczyński ${ }^{a}$

a Department of Bioorganic Chemistry, Faculty of Chemistry, Adam Mickiewicz University, Umultowska 89b, 61-614 Poznań, Poland

${ }^{b}$ Bob Champion Research \& Education Building, Norwich Medical School, University of East Anglia, Norwich, UK

${ }^{c}$ Institute of Low Temperature and Structure Research, Polish Academy of Sciences, PO Box 1410, 50-950 Wrocław, Poland

Keywords: Polyether ionophores; Allylic hydroxyl oxidation; Reductive amination; Antiparasitic activity; African trypanosomiasis; Trypanosoma brucei; Crystal structure

\section{Corresponding Author}

*E-mail: michant@amu.edu.pl (M. Antoszczak) 
Abstract: As a group of biologically active compounds, polyether antibiotics (ionophores) show a broad spectrum of interesting pharmacological properties, ranging from anti-bacterial to anticancer activities. There is increasing evidence that ionophores, including salinomycin (SAL), and their semi-synthetic analogues are promising candidates for the development of drugs against parasitic diseases. Our previous studies have shown that esterification and amidation of the C1 carboxylate moiety of SAL provides compounds with potent activity against Trypanosoma brucei, protozoan parasites responsible for African trypanosomiasis. In this paper, we present the synthetic pathways, crystal structures and anti-trypanosomal activity of $\mathrm{C} 1$ esters, amides and hydroxamic acid conjugates of SAL, its C20-oxo and propargylamine analogues as well novel C1/C20 doubly modified derivatives. Evaluation of the trypanocidal and cytotoxic activity using bloodstream forms of Trypanosoma brucei and human myeloid HL-60 cells revealed that the single-modified C20-oxo and propargylamine precursor molecules $\mathbf{1 0}$ and $\mathbf{1 6}$ were the most anti-trypanosomal and selective compounds with $50 \%$ growth inhibition $\left(\mathrm{GI}_{50}\right)$ values of 0.037 and $0.0035 \mu \mathrm{M}$, and selectivity indices of 252 and 300 , respectively. Also the salicylhydroxamic acid conjugate of SAL (compound 9) as well as benzhydroxamic acid and salicylhydroxamic acid conjugates of 10 (compounds 11 and 12) showed promising trypanocidal activities with $\mathrm{GI}_{50}$ values between 0.032 to $0.035 \mu \mathrm{M}$ but less favorable selectivities. The findings confirm that modification of SAL can result in derivatives with improved trypanocidal activity that might be interesting lead compounds for further anti-trypanosomal drug development. 


\section{Introduction}

Polyether ionophores have been used in veterinary medicine for decades as non-hormonal growth promoters and as agents to control coccidiosis [1-2]. In addition to the industrial use of ionophores in animal husbandry [3], some of them show anti-fungal, anti-viral, and anti-cancer activity [4-6]. Salinomycin (SAL, 1, Scheme 1), a polyether $\mathrm{K}^{+}$-selective membrane ionophore from Streptomyces albus, seems to be the most promising agent in this context as several studies have shown activity against different human cancer cells, multi-drug resistant cancer cells, cancer stem cells and human tumour xenograft models in mice [5]. Although accidental poisonings have been reported, SAL was found to improve the condition in a small group of cancer patients without any long-term acute adverse effects when used in the appropriate dose [5,7-8]. Mechanistically, the effects on several signal transduction pathways were suggested to explain the change in phenotype composition after SAL treatment, including Wnt signaling pathway involved in tumorigenesis and embryogenesis. Other pathways that were inhibited by SAL include KRas and modulation of Hedgehog signaling [5].

It should be pointed out that compounds that display anti-cancer activity, very often are also active against African trypanosomes [9]. These protozoan parasites cause sleeping sickness in humans and nagana disease in cattle [10-12], and are transmitted by the bites of infected tsetse flies (Glossina sp.) that are only found in rural regions of sub-Saharan Africa [13-14]. Historically, African trypanosomiasis has been a serious economic and public health problem in Africa, causing several epidemics over the last century [15]. According to the World Health Organization, the estimated number of actual cases is below 20,000, but the estimated population at risk is still 65 million people [16]. Because of nagana disease, livestock farming is difficult in many regions of sub-Saharan Africa and this is exacerbated by the rise of drug resistant 
trypanosomes [10]. As the few drugs that are used for treatment of both sleeping sickness and nagana disease are outdated, have limited efficacy and may produce adverse side reactions [17-19], novel and better-tolerated therapeutic strategies are a critical need.

Recently, we have demonstrated that SAL and semi-synthetic SAL derivatives obtained by chemical modification of the $\mathrm{C} 1$ carboxylate moiety inhibit the growth of culture-adapted bloodstream forms of Trypanosoma brucei in vitro at sub-micromolar concentration [20]. Interestingly, certain SAL analogues have been found to display enhanced trypanocidal activity compared to that of the parent ionophore with $\mathrm{GI}_{50}$ values in the mid nanomolar range and MIC values below $1.0 \mu \mathrm{M}$. These anti-trypanosomal activities are within the range of the drugs used to treat African trypanosomiasis [20].

Besides C1 carboxylate moiety [20-23], the allylic C20 hydroxyl group of SAL has also been found to be an interesting site for chemical modification, as $\mathrm{C} 20-O$-acyl and $\mathrm{C} 20$-amine derivatives have been shown to have an improved biological activity profile compared to that of unmodified compound [24-25]. Recently, we have reported that doubly $\mathrm{C} 1 / \mathrm{C} 20$ modified analogues of SAL display anti-cancer activity in the low $\mu \mathrm{M}$ range with low toxicity towards normal cells. In addition, these derivatives also showed good activity against a multi-drug resistant cancer cell line [26]. These findings indicate that multiple modifications of the SAL molecule may be also a promising synthetic strategy to improve the biological activity of this ionophore against T. brucei.

On the basis of our recent findings, we designed a completely novel class of multiply modified SAL derivatives by merging desirable structural features to generate promising antitrypanosomal agents. In this context, methods for efficient synthetic access to novel doublemodified analogues of C20-oxo and C20-propargylamine derivatives of a series of selected $\mathrm{C} 1$ 
esters, amides and hybrids with hydroxamic acids are presented (Schemes 1-3). The newly synthesized compounds were evaluated in vitro for their trypanocidal and cytotoxic activity using bloodstream form of T. brucei and human myeloid HL-60 cells, respectively. The trypanocidal mechanism of the most active derivatives was investigated by swelling experiments. 

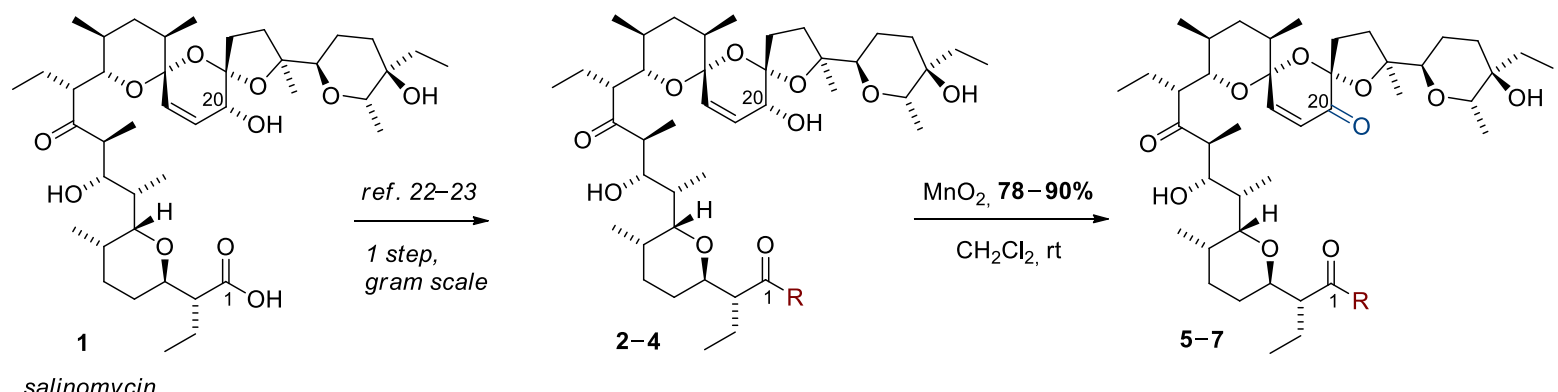

\begin{tabular}{|c|c|c|}
\hline $\mathrm{R}=$ & $\begin{array}{l}\text { C20 } \\
\text { hydroxyl }\end{array}$ & $\begin{array}{l}\text { C20 } \\
\text { ketone }\end{array}$ \\
\hline & 2 & 5 \\
\hline & 3 & 6 \\
\hline H & 4 & 7 \\
\hline
\end{tabular}

Scheme 1. Synthesis ofC1 esters and amides of C20-oxo-salinomycin.

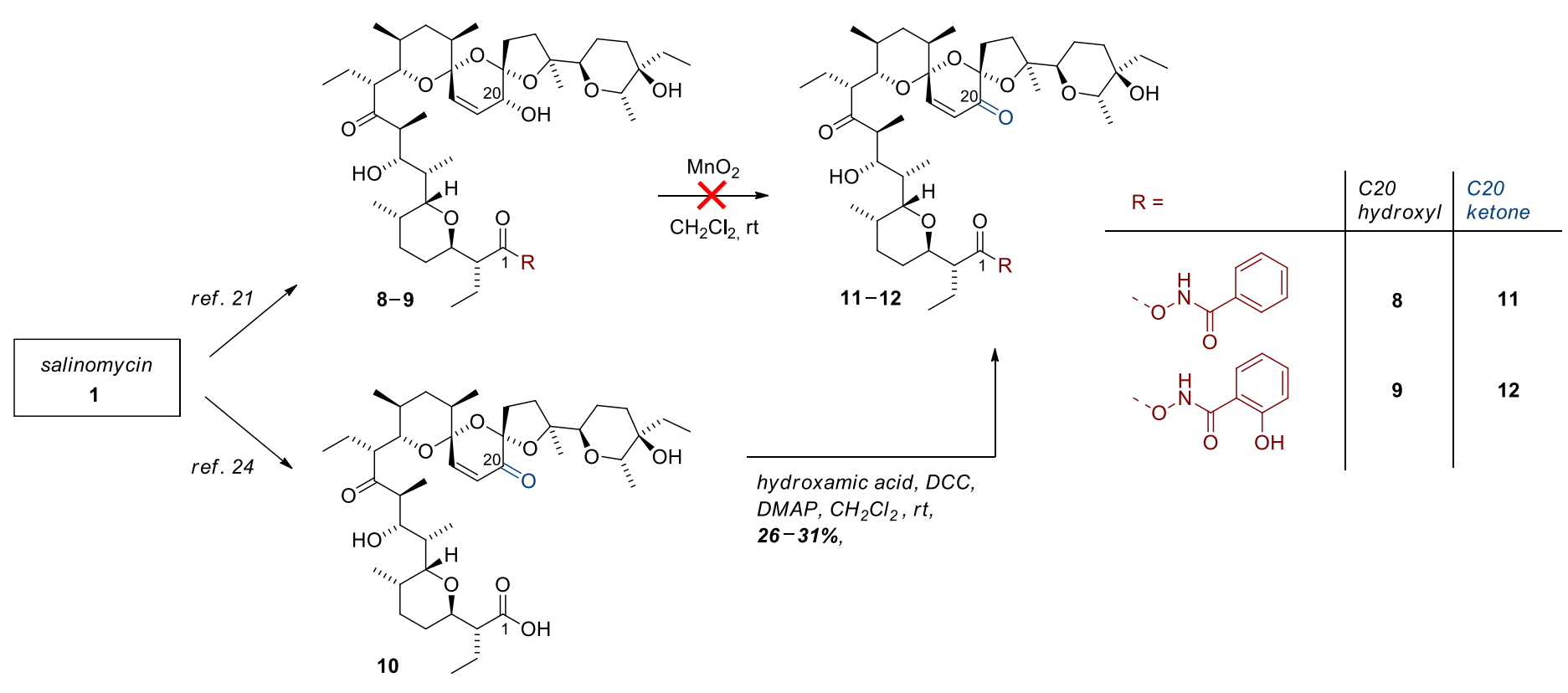

Scheme 2. Synthesis ofC1 conjugates of 220 -oxo-salinomycin with hydroxamic acids. 


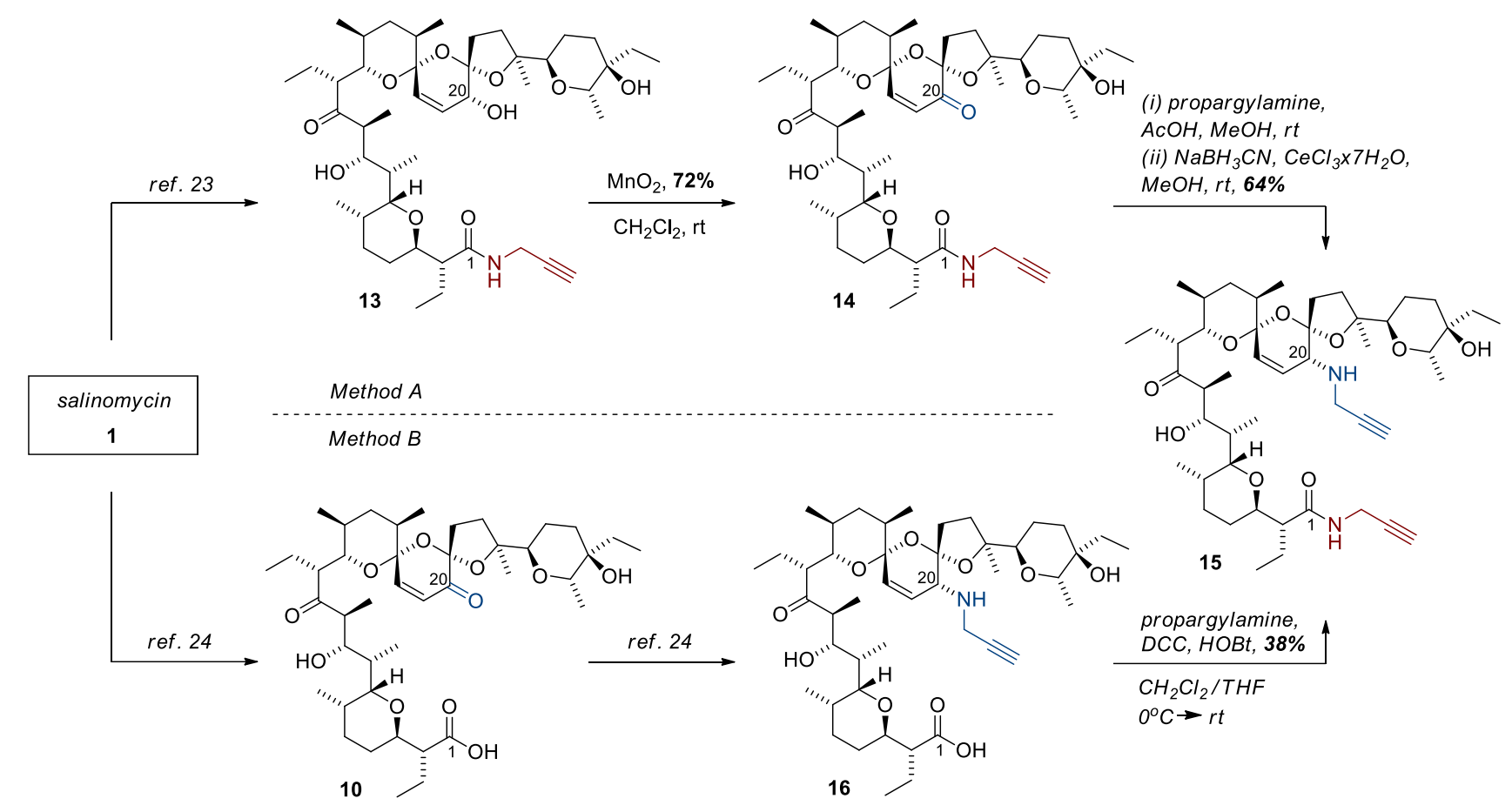

Scheme 3. Synthesis of double-modified analogues 14 and 15. 


\section{Results and discussion}

\subsection{Analogue design and synthesis}

Firstly, to expand the library of novel doubly $\mathrm{C} 1 / \mathrm{C} 20$ modified compounds, SAL analogues were designed on the basis of the most active $\mathrm{C} 1$ esters, amides and conjugates with hydroxamic acids obtained in previous studies [21-23], i.e. ester $\mathbf{2}$ and amide $\mathbf{4}$ (Sche me 1) as well as hybrids 8 and 9 (Scheme 2). Secondly, propargyl ester 3 (Sche me 1) and propargyl amide 13 (Scheme 3) were also included in our studies because of their structural similarity that might be of help in determination of structure-activity relationship (SAR). In addition, both structures were previously shown to display promising biological activity [23]. Thirdly, with respect to the modification of the $\mathrm{C} 20$ position, chemoselective oxidation of $\mathrm{C} 20$ hydroxyl was performed for all mentioned compounds to give access to six novel C20-oxo analogues (Schemes 1-3). Further stereoselective reductive amination of enone 14 (Scheme 3) was executed as well, as such a modification was expected to improve the biological activity of the resulting double-modified analogue (Scheme 3, compound 15) [24]. Finally, to compare the trypanocidal activity of corresponding derivatives as well as to facilitate SAR analysis, both SAL precursors, C20 ketone 10 and C20 amine 16, were also synthesized (Sche me 2 and 3) [24].

The allylic C20 hydroxyl group of the series of $\mathrm{C} 1$ esters and amides was chemoselectively oxidized to the corresponding C20 ketones with moderate to good yields (7290\%) using activated manganese(IV) oxide (Scheme 1, compounds 5-7 and Scheme 3, compound 14) [24]. In all cases, full selectivity towards the C20 hydroxyl was observed. The synthesis of the double-modified analogues 11 and 12 (Sche me 2) was, however, slightly more challenging as the C20 hydroxyl group of the SAL hybrids with hydroxamic acids did not undergo oxidation under the reaction conditions. In order to obtain these compounds, it was 
therefore necessary to synthesize C20-oxo-salinomycin $\mathbf{1 0}$ prior to its conjugation with benzhydroxamic acid or salicylhydroxamic acid (Scheme 2).

In 2017, Rodriguez and co-workers synthesized a series of C20-amine derivatives of SAL and found that the C20-propargylamine analogue (Scheme 3, compound 16) was the most interesting one. The compound showed almost 10-times higher anti-proliferative activity against breast cancer stem cells than $\mathbf{S A L}$, both in vitro and in vivo, with $\mathrm{IC}_{50}$ value of $\sim 100 \mathrm{nM}$ whilst maintaining selectivity over control cells [24]. This finding inspired us to obtain a novel doubly modified analogue of SAL by transforming compound $\mathbf{1 4}$ to its corresponding C20propargylamine 15 (Scheme 3, Method A), according to the protocol mentioned above [24]. In the first step of reductive amination, enone $\mathbf{1 4}$ reacted with propargylamine in the presence of acetic acid to form the imine in situ. Using the Luche reduction, the intermediate imine was then reduced by the slow addition of $\mathrm{NaBH}_{3} \mathrm{CN}$ in the presence of $\mathrm{CeCl}_{3}$, which resulted in the stereoselective formation of the novel double-modified derivative 15 with 64\% yield (Sche me 3, Method A). Compound $\mathbf{1 5}$ was also obtained using the 'reversed' reaction sequence. Ketone 10 was converted into amine 16 [24], followed by an amidation reaction of C1 carboxyl moiety that resulted in the formation of $\mathbf{1 5}$ with 38\% yield (Scheme 3, Method B). The overall yield of this transformation was however lower than the first one.

The purity and structure of the newly synthesized compounds were determined using scXRD, spectroscopic (FT-IR, NMR) and spectrometric (ESI MS) methods. The ${ }^{1} \mathrm{H}$ and ${ }^{13} \mathrm{C}$ NMR spectra of selected SAL precursors and all novel double-modified analogues are included in Supplementary Information. The ${ }^{19} \mathrm{~F}$ NMR spectra of $\mathbf{5}$ and $\mathbf{7}$ that contain additional fluorine atoms in their structures are also included (see Supplementary Information). Briefly, in the ${ }^{13} \mathrm{C}$ NMR spectra (in $\mathrm{CD}_{2} \mathrm{Cl}_{2}$ or in $\mathrm{CDCl}_{3}$ ) of double-modified derivatives, the most 
characteristic signal of $\alpha, \beta$-unsaturated ketone at the $\mathrm{C} 20$ position was observed in a narrow range of $189.3-190.5 \mathrm{ppm}$. In the ${ }^{1} \mathrm{H}$ NMR spectrum of 15, the characteristic signal of the alkynyl hydrogen of the C20 terminal alkyne moiety was observed at $2.21(\mathrm{t}, J=2.4 \mathrm{~Hz}, 1 \mathrm{H})$ ppm.

\subsection{X-rayanalysis}

Structural data of SAL derivatives are very important to understand their biological properties, to determine SAR as well as related investigation. We have therefore characterized compounds 14 and 15 using the single-crystal X-ray diffraction (scXRD) method, and compared the obtained structures to the structure of the propargyl amide $\mathbf{1 3}$ described previously [27].

Single crystals of 14 (mp 115-119 ${ }^{\circ} \mathrm{C}$ ) and $\mathbf{1 5}\left(\mathrm{mp} \mathrm{169-173}{ }^{\circ} \mathrm{C}\right)$ were grown by crystallisation in acetonitrile solution. Compound $\mathbf{1 4}$ crystallized in the non-centrosymmetric space group $\mathrm{P} 2_{1}$ of the monoclinic system with one molecule in the asymmetric unit, while compound 15 crystallized in the non-centrosymmetric space group of the triclinic system with two molecules in the asymmetric unit. Crystal data and details of the refinement parameters are presented in Table S1 (Supplementary Information). The asymmetric unit of the SAL derivatives 14 and 15 is illustrated in Figure 1 and Figure 2, respectively. 


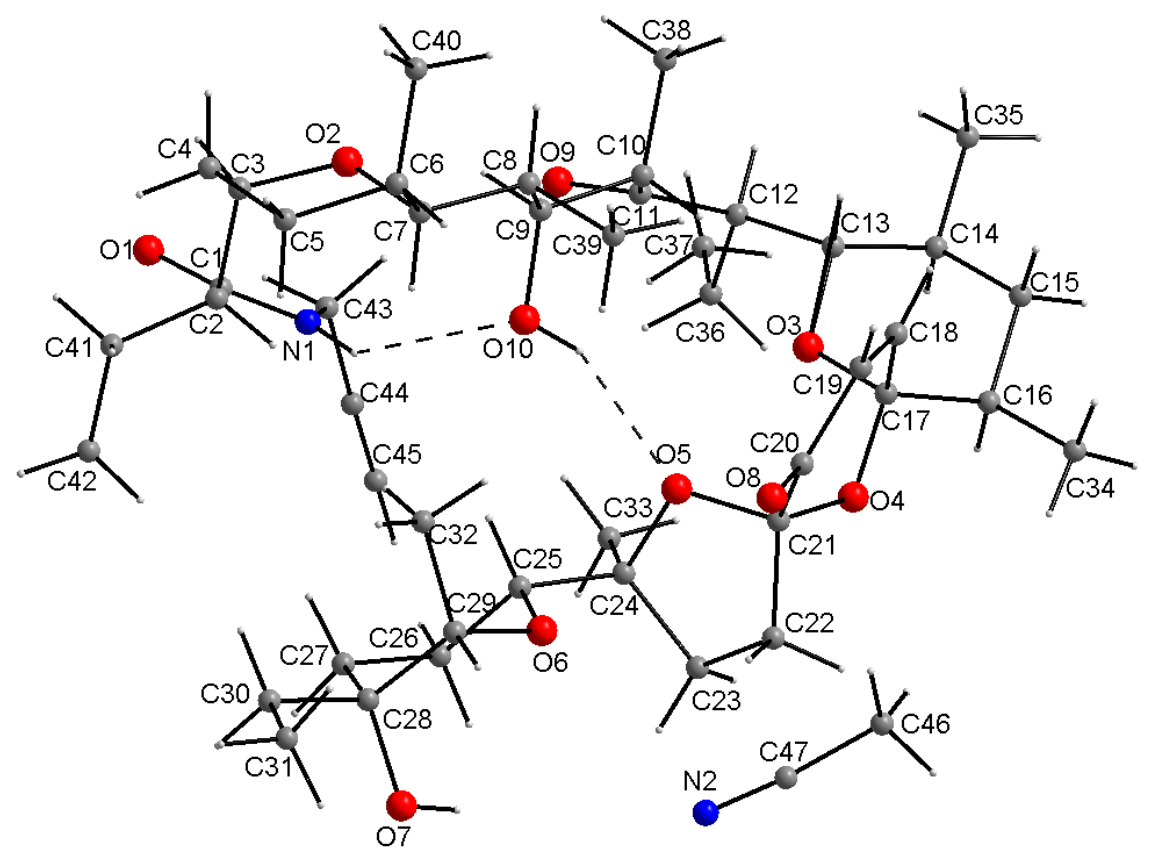

Figure 1. View of the as ymmetric unit of 14. 

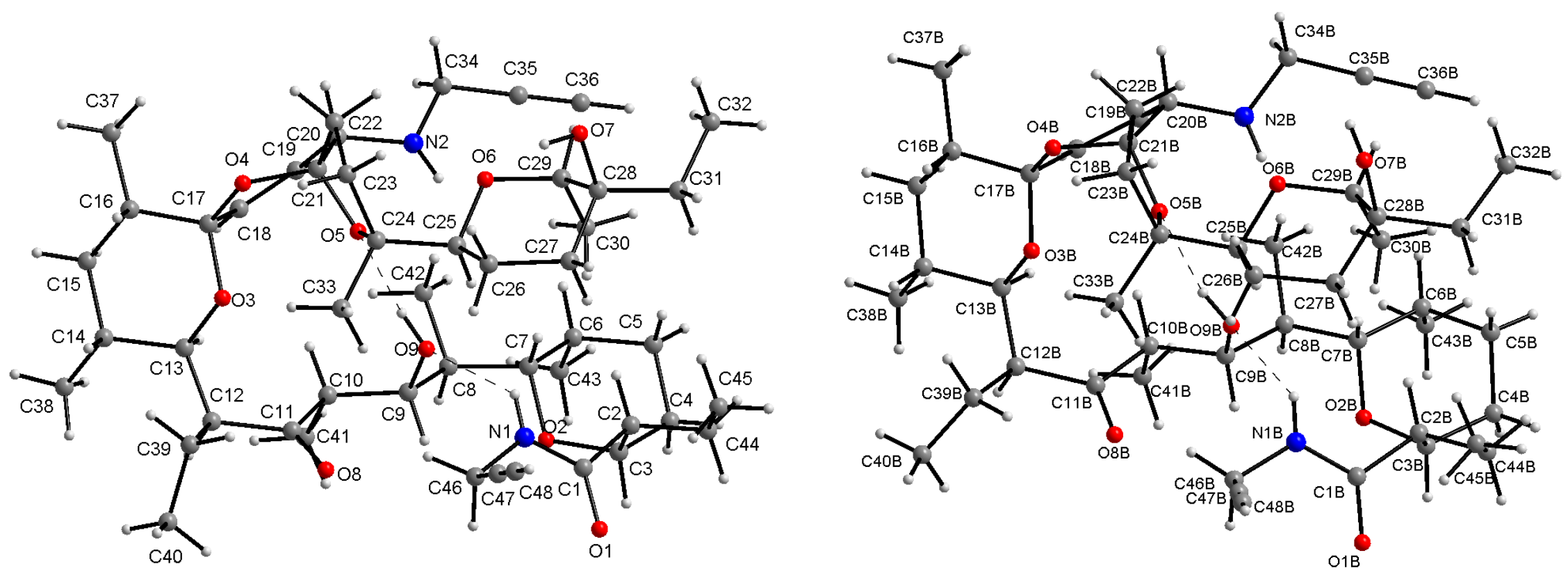

Figure 2. View of the asymmetric unit of 15 (Mol. 1 on the left, and Mol. 1B on the right). 
In the crystals, the molecules of both SAL derivatives exhibit pseudo-cyclic conformation. This conformation is stabilized by the $\mathrm{O}-\mathrm{H} \cdots \mathrm{O}$ hydrogen bond formed by the hydroxyl group linked to $\mathrm{C} 9$ carbon atom and the $\mathrm{O} 5$ oxygen atom of the five-membered ring of the spiroketal system (Supplementary Information, Table S2) and, in addition, by an $\mathrm{N}-\mathrm{H} \cdots \mathrm{O}$ hydrogen bond formed by the $\mathrm{N}-\mathrm{H}$ of the amide group as a donor and the hydroxyl group as an acceptor that adds partly into the stabilization energy of the pseudo-cyclic conformation (Figure 2). Both independent molecules in the crystal of 15 (Mol. 1 and Mol. 1B) exhibit similar conformation (Supplementary Information, Figure S1), but differ from that of 14 due to the substitution effect at the C20 atom (Supple mentary Information, Figure S2). The spiroketal system consists of two six-membered and one five-membered rings, in which the central rings are unsaturated. The arrangement of the atoms around the $\mathrm{C} 17$ and $\mathrm{C} 21$ heads is tetrahedral, so that the junctions between the five- and six-membered rings and between both sixmembered rings are of the spiro type. The unsaturated six-membered ring with one double bond character $(\mathrm{C} 18=\mathrm{C} 19)$, with a distance of $1.326(5) \AA$ in $\mathbf{1 4}$ and 1.304(10) and 1.313(9) $\AA$ in the independent Mol. 1 and Mol. 1B molecules in 15, has envelope conformation where C21 is out of the plane formed by the other ring atoms by $0.388(5) \AA$ in $\mathbf{1 4}$, and $0.508(8)$ and $0.486(8) \AA$ in Mol. 1 and Mol. 1B in 15, respectively. The five-membered ring of the spiro system exhibits twisted conformation with the $\mathrm{C} 21$ atom out of the mean plane defined by the other atoms of the ring by $0.443(5) \AA$ in 14, and $0.414(8)$ and 0.411(8) $\AA$ in Mol. 1 and Mol. 1B in 15, respectively. All saturated six-membered rings exhibit chair conformation in both $\mathbf{1 4}$ and $\mathbf{1 5}$ structures. The X-ray crystallographic analysis confirmed the structural assignment (Scheme 3). The pseudocyclic conformation of $\mathbf{1 4}$ is quite similar to the conformation of SAL propargyl amide $\mathbf{1 3}$ (Supplementary Information, Figure S3), but the pseudo-cyclic conformation of $\mathbf{1 5}$ due to the 
substitution effect at C20 is different to that of SAL propargyl amide 13 (Supplementary Information, Figure S4) [27].

\subsection{Anti-trypanosomal activity}

All SAL precursors and their newly synthesized double-modified derivatives were evaluated for their in vitro activity against bloodstream forms of T. brucei and human myeloid HL-60 cell using the resazurin cell viability assay [28,29]. All compounds showed a dosedependent inhibitory effect on the growth of bloodstream-form trypanosomes (Table 1). Of the single-modified $\mathrm{C} 1$ esters and amides, only the benzhydroxamic acid conjugate 9 displayed a 6fold enhanced trypanocidal activity compared to that of SAL with a $50 \%$ growth inhibition $\left(\mathrm{GI}_{50}\right)$ value of $0.035 \mu \mathrm{M}$. Both single-modified C20 analogues, C20-oxo and C20propargylamine derivatives $\mathbf{1 0}$ and 16, also exhibited increased anti-trypanosomal activity with similar $\mathrm{GI}_{50}$ values. Of the double-modified compounds, the benzhydroxamic acid and salicylhydroxamic acid conjugates 11 and 12 showed improved trypanocidal activity with $\mathrm{GI}_{50}$ values of 0.032 and $0.034 \mu \mathrm{M}$. However, their anti-trypanosomal activity was not better than that of their parent compound $\mathbf{1 0}$. 
Table 1. $\mathrm{GI}_{50}$ values and ratios of S AL derivatives for T. brucei and HL-60 cells.

Single-modifieds alinomycin derivatives

Double-modified salinomycin derivatives
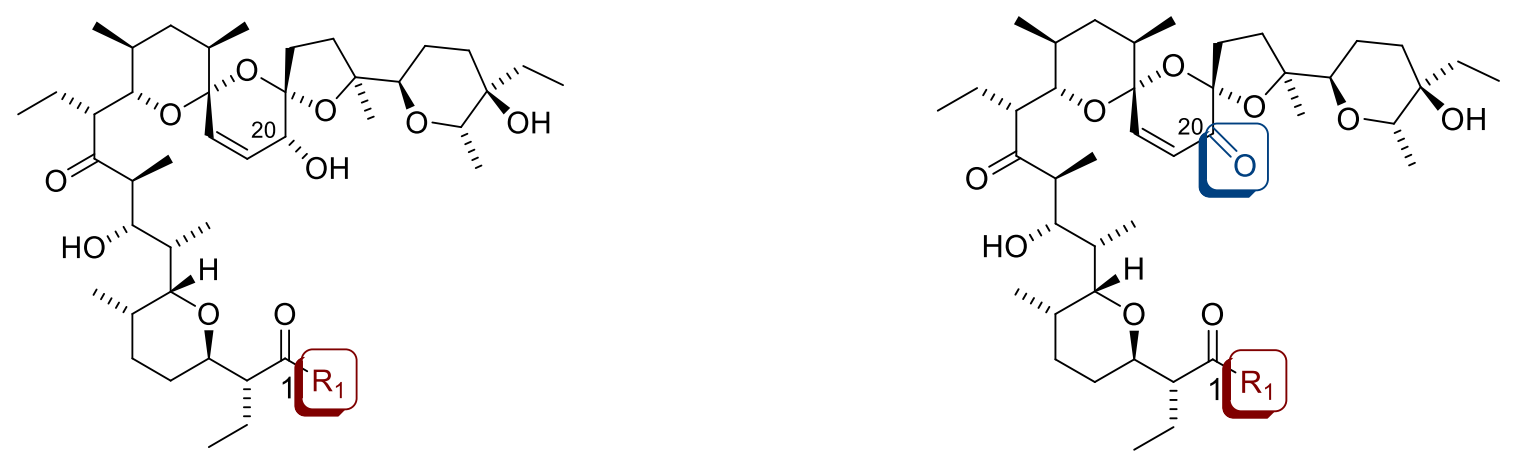

\begin{tabular}{|c|c|c|c|c|c|c|c|c|}
\hline \multirow{2}{*}{ No. } & \multirow{2}{*}{$\mathbf{R}_{1}$} & T. brucei & HL-60 & Selectivity & \multirow{2}{*}{ No. } & T. brucei & HL-60 & Selectivity \\
\hline & & $\mathrm{GI}_{50}(\mu \mathrm{M})^{\mathrm{a}}$ & $\mathrm{GI}_{50}(\mu \mathrm{M})^{\mathrm{a}}$ & $\mathrm{GI}_{50}$ ratio $^{\mathrm{b}}$ & & $\mathrm{GI}_{50}(\mu \mathrm{M})^{\mathrm{a}}$ & $\mathrm{GI}_{50}(\mu \mathrm{M})^{\mathrm{a}}$ & $\mathrm{GI}_{50}$ ratio $^{\mathrm{b}}$ \\
\hline 1 & $--\mathrm{OH}$ & $0.21 \pm 0.06$ & $6.63 \pm 3.23$ & 31.6 & 10 & $0.037 \pm 0.005$ & $9.21 \pm 4.25$ & 252 \\
\hline 2 & & $2.90 \pm 0.19$ & $32.5 \pm 0.8$ & 11.2 & 5 & $3.01 \pm 0.34$ & $>100$ & $>33.2$ \\
\hline 3 & & $2.93 \pm 0.14$ & $30.0 \pm 1.9$ & 10.2 & 6 & $3.03 \pm 0.06$ & $29.6 \pm 2.0$ & 9.8 \\
\hline 4 & & $2.87 \pm 0.05$ & $11.6 \pm 1.6$ & 4.0 & 7 & $2.99 \pm 0.11$ & $94.7 \pm 7.7$ & 31.7 \\
\hline 8 & & $0.17 \pm 0.08$ & $3.58 \pm 0.98$ & 21.1 & 11 & $0.032 \pm 0.001$ & $2.24 \pm 0.87$ & 70.0 \\
\hline
\end{tabular}


<smiles>CONC(=O)c1ccccc1O</smiles>

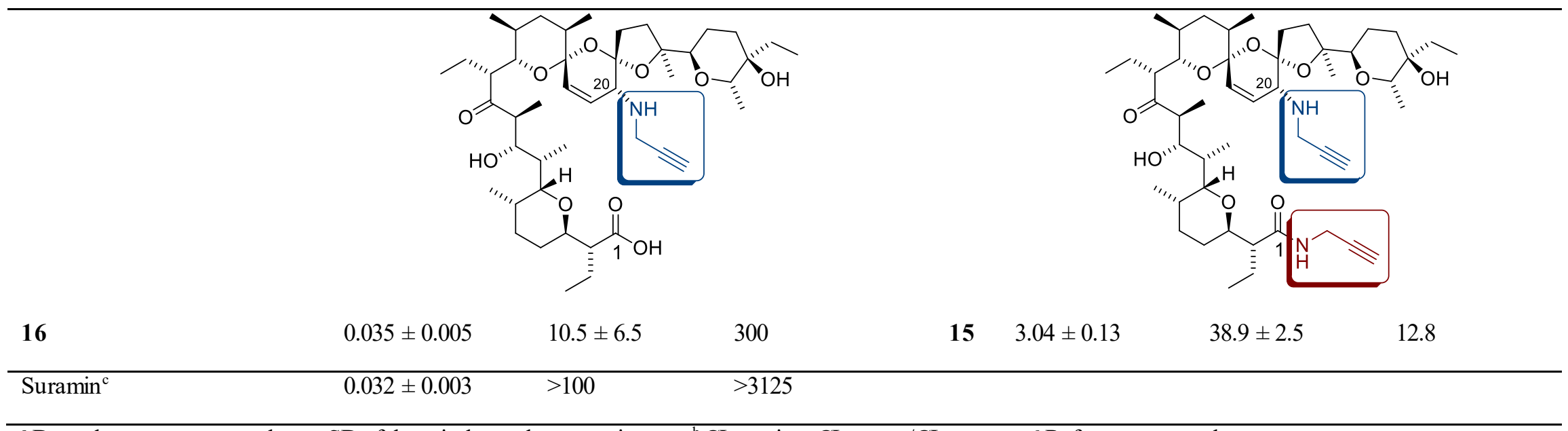

${ }^{\mathrm{a}}$ Data shown are mean values $\pm \mathrm{SD}$ of three independent experiments $;{ }^{\mathrm{b}} \mathrm{GI}_{50}$ ratio $=\mathrm{GI}_{50(\mathrm{HL}-60)} / \mathrm{GI}_{50(T .}$ brucei $),{ }^{\mathrm{c}}$ Reference control. 
Most derivatives showed lower cytotoxic activity against HL-60 cells than SAL (Table 1). However, compounds $\mathbf{9 , 1 1}$ and 12 displayed increased cytotoxicities. As the single modified C20 derivatives were less cytotoxic towards HL-60 cells, their selectivity index (GI ${ }_{50}$ ratio of cytotoxic to trypanocidal activity) was $8-9$ fold increased relative to that of SAL (Table 1).

Noteworthy is the finding that all five compounds $(9-12$ and 16) with increased trypanocidal activity displayed $\mathrm{GI}_{50}$ values similar to the $\mathrm{GI}_{50}$ value of suramin, one of the drugs used in the treatment of sleeping sickness (Table 1). However, as suramin is nontoxic to HL-60 cells, the selectivity indices of the derivatives were less favorable than the $\mathrm{GI}_{50}$ ratio of suramin,

It has been shown that SAL derivatives with enhanced trypanocidal activity display increased ionophoretic activity when compared to that of the unmodified parent compound [20]. Therefore, we wanted to check whether the enhanced anti-trypanosomal activity of compounds 9-12 and 16 was also due to increased ionophoresis. Changes in cell volume were determined by swelling experiments using the light scattering method previously described [20]. Only the C20oxo derivative 10 produced an increased swelling in bloodstream-form trypanosomes while the C20-propargylamine derivative $\mathbf{1 6}$ generated a similar swelling in the parasites as the parent compound (Figure 3). The other three compounds displayed lower (9) and much lower (11 and 12) ionophoresis (Figure 3). Based on their low $\mathrm{GI}_{50}$ values $(0.032-0.035 \mu \mathrm{M}$, Table 1) in connection with their low ionophoretic activity, the trypanocidal activity of compounds $\mathbf{9 , 1 1}$ and 12 may be not only due to their ionophoretic properties but probably to other mechanisms of toxic action. 


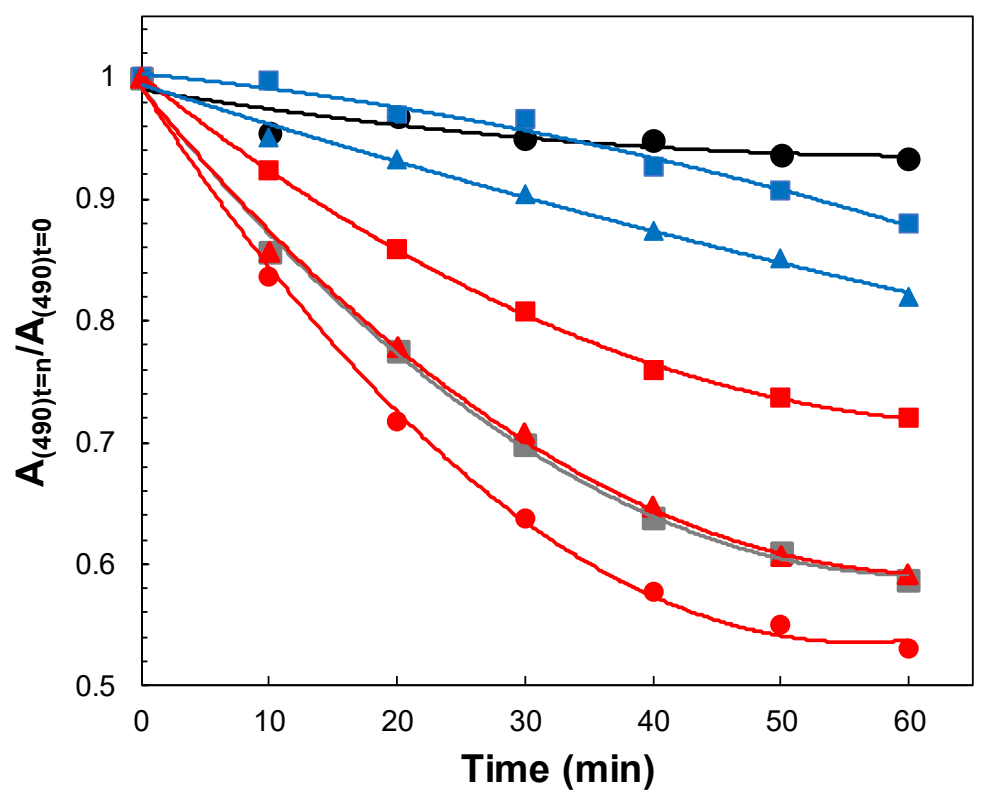

Figure 3. Effect of SAL derivatives on the cell volume of bloodstream forms of T. brucei. Trypanoso me s (5 × $10^{7}$ cells ml ${ }^{-1}$ ) were incubated with $100 \mu \mathrm{M}$ ionophore in Baltz medium in the presence of $0.9 \%$ DMSO. Every $10 \mathrm{~min}$, the absorbance at $490 \mathrm{~nm}$ was measured. Black circles, DMSO control; grey squares, SAL control; red, singlemodified derivatives (squares, 9; circles, 10; triangles, 16); blue, double-modified derivatives (squares, 11; triangles, 12). Note that a decrease in absorbance corresponds to an increase in cell volume. For clarity, only mean values of three experiments are shown. The standard deviations ranged from 0.1 to 12.1 percentage points.

Evaluation of the trypanocidal activity of the new SAL derivatives has shown that modification of the $\mathrm{C} 20$ hydroxyl group to its ketone and propargylamine analogues $\mathbf{1 0}$ and $\mathbf{1 6}$ gave compounds with increased anti-trypanosomal activity. Further modification of $\mathbf{1 0}$ or $\mathbf{1 6}$ at their $\mathrm{C} 1$ position did not lead to an additional increase in trypanocidal activity. The antitrypanosomal activity of the double-modified compounds was either decreased $(5-7,14$ and 15$)$ or stayed the same (11 and 12). As the cytotoxic activity of the double-modified derivatives paralleled their trypanocidal activity, their selectivity was not much different from that of SAL.

\section{Conclusions}


In summary, a series of novel double-modified SAL analogues derivatized at their $\mathrm{C} 1 / \mathrm{C} 20$ positions was devised. All newly designed compounds were synthesized in moderate to good yields. Of advantage were the straightforward protocols that allowed simple reaction workup and convenient isolation of the analogues.

X-ray single crystal analyses of both SAL derivatives $\mathbf{1 4}$ and $\mathbf{1 5}$ showed pseudo-cyclic conformation of the skeletal molecules that were stabilized by the intramolecular $\mathrm{O}-\mathrm{H} \cdots \mathrm{O}$ and $\mathrm{N}-\mathrm{H} \cdots \mathrm{O}$ hydrogen bonds. A slight differences in the conformation between these SAL derivatives resulted from the substitution effect at the carbon atom C20 in the unsaturated sixmembered ring.

With respect to trypanocidal activity, double-modified derivatives showed at best antitrypanosomal activity similar to that of their single-modified starting molecules, wherein compounds 11 and 12 seem to be the most promising ones in this group. However, their selectivity was not significantly improved. The most trypanocidal and selective compounds were the SAL derivatives $\mathbf{1 0}$ and $\mathbf{1 6}$ that were single-modified at their C20 position. These two analogues match the activity criteria for drug candidates for African trypanosomiasis $\left(\mathrm{GI}_{50}<1\right.$ $\mu \mathrm{M}$; selectivity $>100)$.

\section{Expe rimental}

\subsection{General procedures}

All precursors (except for hydroxamic acids, see section 4.2 for details) and all solvents were obtained from Merck or Trimen Chemicals S.A. (Poland), and were used as received without further purification. $\mathrm{CD}_{2} \mathrm{Cl}_{2}$ and $\mathrm{CDCl}_{3}$ spectral grade solvents were stored over $3 \AA$ molecular sieves for several days. All manipulations were carried out under nitrogen atmosphere 
in oven-dried glassware. Reaction mixtures were stirred using teflon-coated magnetic stir bars. Reaction mixtures were monitored by thin layer chromatography (TLC) using aluminum-backed plates (Merck 60F254). TLC plates were visualized by UV-light $(254 \mathrm{~nm})$, followed by treatment with phosphomolybdic acid (PMA, 5\% in absolute EtOH) and gentle heating. Products of the reactions were purified using CombiFlash ${ }^{\circledR} \mathrm{Rf}+$ Lumen Flash Chromatography System (Teledyne Isco) with integrated ELS and UV detectors. All solvents used in flash chromatography were of HPLC grade (Merck) and were used as received. Solvents were removed using a rotary evaporator.

NMR spectra were recorded on a Varian $400\left({ }^{1} \mathrm{H}\right.$ NMR at $403 \mathrm{MHz},{ }^{13} \mathrm{C}$ NMR at 101 $\mathrm{MHz}$, and ${ }^{19} \mathrm{~F}$ NMR at 379 or $282 \mathrm{MHz}$ ) magnetic resonance spectrometer. ${ }^{1} \mathrm{H}$ NMR spectra are reported in chemical shifts downfield from TMS using the respective residual solvent peak as internal standard $\left(\mathrm{CD}_{2} \mathrm{Cl}_{2} \delta 5.32 \mathrm{ppm}\right.$ and $\left.\mathrm{CDCl}_{3} \delta 7.26 \mathrm{ppm}\right) .{ }^{1} \mathrm{H}$ NMR spectra are reported as follows: chemical shift $(\delta, \mathrm{ppm})$, multiplicity $(\mathrm{s}=$ singlet, $\mathrm{d}=$ doublet, $\mathrm{t}=$ triplet, $\mathrm{q}=$ quartet, hept $=$ heptet, $\mathrm{dd}=$ doublet of doublets, $\mathrm{dt}=$ doublet of triplets, $\mathrm{dq}=$ doublet of quartets, $\mathrm{ddd}=$ doublet of doublet of doublets, ddt $=$ doublet of doublet of triplets, dtd $=$ doublet of triplet of doublets, $\mathrm{td}=$ triplet of doublets, $\mathrm{tdd}=$ triplet of doublet of doublets, $\mathrm{qd}=$ quartet of dublets, $\mathrm{m}=$ multiplet), coupling constant(s) in $\mathrm{Hz}$, and integration. Significant peaks are reported within the overlapping $\sim 2.00-0.50 \mathrm{ppm}$ region of the ${ }^{1} \mathrm{H}$ NMR spectra. ${ }^{13} \mathrm{C}$ NMR spectra are reported in chemical shifts downfield from TMS using the respective residual solvent peak as internal standard $\left(\mathrm{CD}_{2} \mathrm{Cl}_{2} \delta 53.84 \mathrm{ppm}\right.$ and $\left.\mathrm{CDCl}_{3} \delta 77.16 \mathrm{ppm}\right) .{ }^{19} \mathrm{~F}$ NMR spectra are reported in chemical shifts upfield from TMS using $\mathrm{CFCl}_{3}$ as internal standard. Line broadening parameters were 0.5 or $1.0 \mathrm{~Hz}$, while the error of chemical shift value was $0.1 \mathrm{ppm}$. 
Infrared spectra in the mid infrared region were recorded in $\mathrm{KBr}$ tablets on an IFS $113 \mathrm{v}$ FT-IR spectrophotometer (Bruker) equipped with a DTGS detector, and are reported as follows: wavenumbers $\left(\mathrm{cm}^{-1}\right)$, description $(\mathrm{w}=$ weak, $\mathrm{m}=$ medium, $\mathrm{s}=$ strong, $\mathrm{br}=$ broad $)$. The spectra were taken on resolution $2 \mathrm{~cm}^{-1}$, NSS $=64$. The Happ-Genzel apodization function was used.

Electrospray ionization (ESI) mass spectra were recorded on a Waters/Micromass ZQ mass spectrometer (Waters Alliance) equipped with a Harvard syringe pump. Samples were prepared in dry acetonitrile, and were infused into the ESI source using a Harvard pump at a flow rate of $20 \mathrm{ml} \mathrm{min}-1$. The ESI source potentials were: capillary $3 \mathrm{kV}$, lens $0.5 \mathrm{kV}$, and extractor 4 V. Standard ESI mass spectra were recorded at the cone voltages of 10 and $30 \mathrm{~V}$. The source temperature was $120^{\circ} \mathrm{C}$ and the desolvation temperature was $300{ }^{\circ} \mathrm{C}$. Nitrogen was used as the nebulizing and desolvation gas at flow-rates of $100 \mathrm{dm}^{3} \mathrm{~h}^{-1}$. Mass spectra were acquired in the positive ion detection mode with unit mass resolution at a step of $1 \mathrm{~m} / \mathrm{z}$ unit. The mass range for ESI experiments was from $\mathrm{m} / \mathrm{z}=300$ to $\mathrm{m} / \mathrm{z}=1100$.

\subsection{Synthesis}

Salinomycin sodium salt was isolated from commercially available veterinary premix $\mathrm{SACOX}^{\circledR}$ following acidic extraction, using the procedure described by us previously [22-23]. Briefly, isolated sodium salt of salinomycin was dissolved in $\mathrm{CH}_{2} \mathrm{Cl}_{2}$ and stirred vigorously with a layer of aqueous sulphuric acid $(\mathrm{pH}=1.0)$. The organic layer containing SAL was washed with distilled water, and then $\mathrm{CH}_{2} \mathrm{Cl}_{2}$ was evaporated under reduced pressure to dryness giving SAL as a clear oil. After 3-times repeated evaporation with $n$-pentane this oil was transformed to white amorphous solid. The spectroscopic data of SAL were in agreement with previously published data [30]. 
Hydroxamic acid precursors were obtained from the corresponding carboxylic acids according to the procedure published by Jirgensons et al. [31], and used then for the synthesis of SAL conjugates following the procedure described by $\mathrm{Wu}$ et al. [21]. All SAL C1 esters and amides were prepared using the procedures described by us previously [22-23]. Compounds $\mathbf{1 0}$ and 16 were prepared following the procedures described by Rodriguez et al. [24]. The NMR data of all the compounds were in good agreement with those found in the reference literature.

\subsubsection{General procedure for preparation of novel C20-oxo derivatives of salinomycin esters and} amides (analogues 5-7 and 14)

To a stirred solution of SAL ester or amide (1.0 equiv.) in $\mathrm{CH}_{2} \mathrm{Cl}_{2}$ at room temperature, activated manganese(IV) oxide (20.0 equiv.) was added in one portion. The resulting black suspension was stirred vigorously for 3 days, and then filtrated over celite. The filtrate was diluted with $\mathrm{CH}_{2} \mathrm{Cl}_{2}$ and washed with an aqueous solution of $\mathrm{H}_{2} \mathrm{SO}_{4}(\mathrm{pH}=1.0)$ and distilled water. The organic layer was separated and concentrated under reduced pressure to give a colorless oil. Purification on silica gel using the CombiFlash system (EtOAc/ $n$-hexane) gave the pure products of the reactions for 5-7 and 14 (72-90\% yield) as colorless oils. After 3-times repeated evaporation with $n$-pentane the oils were transformed to white amorphous solids.

\subsubsection{2,2,2-trifluoroethyl ester of C20-oxo-salinomycin 5}

Yield: $760 \mathrm{mg}, 88 \%$. Isolated as a white amorphous solid, $>95 \%$ pure by NMR and a single spot by TLC; $\mathrm{R}_{f}: 0.59$ in $33 \%$ EtOAc/ $n$-hexane. UV-active and strains green with PMA; ${ }^{1} \mathrm{H}$ NMR $\left(403 \mathrm{MHz}, \mathrm{CDCl}_{3}\right) \delta 7.24(\mathrm{~d}, J=10.8 \mathrm{~Hz}, 1 \mathrm{H}), 6.23(\mathrm{~d}, J=10.8 \mathrm{~Hz}, 1 \mathrm{H}), 4.75(\mathrm{ddd}, J$ $=17.3,12.9,8.6 \mathrm{~Hz}, 1 \mathrm{H}), 4.65(\mathrm{ddd}, J=17.3,13.0,8.7 \mathrm{~Hz}, 1 \mathrm{H}), 4.06(\mathrm{dd}, J=10.9,5.5 \mathrm{~Hz}, 1 \mathrm{H})$, 
3.88 (ddd, $J=10.1,5.3,1.0 \mathrm{~Hz}, 1 \mathrm{H}), 3.76(\mathrm{q}, J=6.9 \mathrm{~Hz}, 1 \mathrm{H}), 3.64$ (dd, $J=10.1,3.9 \mathrm{~Hz}, 1 \mathrm{H})$, 3.57 (dd, $J=9.8,1.9 \mathrm{~Hz}, 1 \mathrm{H}), 3.48(\mathrm{~s}, 1 \mathrm{H}), 3.42-3.34(\mathrm{~m}, 1 \mathrm{H}), 3.10(\mathrm{td}, J=10.9,4.4 \mathrm{~Hz}, 1 \mathrm{H})$, $2.97(\mathrm{dq}, J=10.1,7.1 \mathrm{~Hz}, 1 \mathrm{H}), 2.78-2.55(\mathrm{~m}, 4 \mathrm{H}), 2.19-2.03(\mathrm{~m}, 2 \mathrm{H}), 2.02-0.66(\mathrm{~m}, 50 \mathrm{H}) \mathrm{ppm}$; ${ }^{13} \mathrm{C}$ NMR (101 MHz, $\left.\mathrm{CDCl}_{3}\right) \delta 214.4,190.4,173.9,143.6,127.3,124.6,121.8,105.4,97.5,88.6$, $78.5,77.1,74.5,72.0,71.9,71.0,70.0,60.8,60.4,57.0,48.8,47.2,39.7,39.0,36.3,34.2,34.1$, $34.0,30.4,29.1,28.0,26.2,22.7,22.5,20.7,19.7,18.9,17.5,15.8,14.3,13.9,12.0,11.5,11.0$, 7.2, $6.4 \mathrm{ppm} ;{ }^{19} \mathrm{~F}$ NMR (282 MHz, chloroform- $d$ ) $\delta-73.97 \mathrm{ppm}$; FT-IR (KBr tablet): 3581 (br, m), 3458 (br, m), 2967 (s), 2939 (s), 2882 (s), 1755 (s), 1736 (m), 1697 (s), 1461 (s), 1446 (s), 1442 (s), $1406 \mathrm{~cm}^{-1}$; ESI MS (m/z): [M+Na $]^{+}$Calcd for $\mathrm{C}_{44} \mathrm{H}_{69} \mathrm{~F}_{3} \mathrm{NaO}_{11} 853$; Found 853.

\subsubsection{Propargyl ester of C20-oxo-salinomycin 6}

Yield: $380 \mathrm{mg}, 79 \%$. Isolated as a white amorphous solid, $>95 \%$ pure by NMR and a single spot by TLC; $\mathrm{R}_{f}: 0.64$ in $33 \%$ EtOAc/n-hexane. UV-active and strains green with PMA; ${ }^{1} \mathrm{H}$ NMR (403 MHz, $\left.\mathrm{CD}_{2} \mathrm{Cl}_{2}\right) \delta 7.23(\mathrm{~d}, J=10.8 \mathrm{~Hz}, 1 \mathrm{H}), 6.19(\mathrm{~d}, J=10.8 \mathrm{~Hz}, 1 \mathrm{H}), 4.82(\mathrm{qd}, J=$ 15.8, $2.5 \mathrm{~Hz}, 2 \mathrm{H}), 3.97(\mathrm{dd}, J=11.0,5.5 \mathrm{~Hz}, 1 \mathrm{H}), 3.84(\mathrm{ddd}, J=10.1,5.0,1.0 \mathrm{~Hz}, 1 \mathrm{H}), 3.72(\mathrm{q}$, $J=6.8 \mathrm{~Hz}, 1 \mathrm{H}), 3.65(\mathrm{dd}, J=10.1,3.4 \mathrm{~Hz}, 1 \mathrm{H}), 3.54(\mathrm{dd}, J=9.8,1.9 \mathrm{~Hz}, 1 \mathrm{H}), 3.41-3.32(\mathrm{~m}$, 1H), $3.02(\mathrm{td}, J=10.7,4.7 \mathrm{~Hz}, 1 \mathrm{H}), 2.93(\mathrm{dq}, J=10.1,7.1 \mathrm{~Hz}, 1 \mathrm{H}), 2.68-2.63(\mathrm{~m}, 2 \mathrm{H}), 2.63-$ $2.51(\mathrm{~m}, 2 \mathrm{H}), 2.13-1.98(\mathrm{~m}, 2 \mathrm{H}), 1.96-0.61(\mathrm{~m}, 52 \mathrm{H}) \mathrm{ppm} ;{ }^{13} \mathrm{C} \mathrm{NMR}\left(101 \mathrm{MHz}, \mathrm{CD}_{2} \mathrm{Cl}_{2}\right) \delta$ $214.5,190.5,175.2,143.9,127.6,105.8,97.9,89.1,79.0,78.6,77.5,75.1,72.6,72.2,71.1,70.4$ $57.0,52.7,49.0,47.5,40.2,39.2,36.7,34.6,34.4,34.2,30.8,29.6,28.5,26.6,23.3,23.1,21.1$, 20.1, 18.7, 17.7, 15.9, 14.5, 14.2, 12.6, 11.8, 11.2, 7.5, 6.6 ppm, one signal overlapped; FT-IR (KBr tablet): 3541 (br, m), 3469 (br, m), 3313 (m), 2966 (s), 2938 (s), 2877 (s), 2124 (w), 1745 
(s), $1724(\mathrm{~s}), 1700$ (s), 1460 (s), 1444 (s), 1405 (s) $\mathrm{cm}^{-1}$; ESI MS (m/z): [M+Na $]^{+}$Calcd for $\mathrm{C}_{45} \mathrm{H}_{70} \mathrm{NaO}_{11} 810$; Found 810 .

\subsubsection{4-fluorophenethyl amide of C20-oxo-salinomycin 7}

Yield: $320 \mathrm{mg}, 90 \%$. Isolated as a white amorphous solid, $>95 \%$ pure by NMR and a single spot by TLC; $\mathrm{R}_{f}: 0.46$ in $50 \%$ EtOAc/n-hexane. UV-active and strains green with PMA; ${ }^{1} \mathrm{H}$ NMR (403 MHz, $\left.\mathrm{CDCl}_{3}\right) \delta$ 7.29-7.22 (m, 3H), 7.00-6.91 (m, 2H), $6.32(\mathrm{t}, J=5.8 \mathrm{~Hz}, 1 \mathrm{H})$, $6.23(\mathrm{~d}, J=10.7 \mathrm{~Hz}, 1 \mathrm{H}), 4.03(\mathrm{dd}, J=9.7,3.2 \mathrm{~Hz}, 1 \mathrm{H}), 3.85(\mathrm{dd}, J=10.8,4.2 \mathrm{~Hz}, 1 \mathrm{H}), 3.78-$ $3.60(\mathrm{~m}, 4 \mathrm{H}), 3.59-3.50(\mathrm{~m}, 1 \mathrm{H}), 3.51-3.47(\mathrm{~m}, 1 \mathrm{H}), 3.35(\mathrm{dd}, J=11.0,2.1 \mathrm{~Hz}, 1 \mathrm{H}), 3.14(\mathrm{~s}$, 1H), 2.93-2.80 (m, 3H), 2.73 (td, $J=10.7,4.4 \mathrm{~Hz}, 1 \mathrm{H}), 2.70-2.65$ (m, 1H), 2.60 (ddd, $J=11.7$, 7.2, $4.0 \mathrm{~Hz}, 1 \mathrm{H}), 2.14-0.56(\mathrm{~m}, 53 \mathrm{H}) \mathrm{ppm} ;{ }^{13} \mathrm{C} \mathrm{NMR}\left(101 \mathrm{MHz}, \mathrm{CDCl}_{3}\right) \delta$ 214.1, 190.1, 175.1, $162.7,160.3,143.4,135.20,135.17,130.34,130.26,127.6,115.1,114.9,105.7,97.4,89.0,78.5$, $77.4,75.3,72.5,71.4,70.8,70.2,55.3,49.0,46.3,40.5,39.7,38.7,36.4,35.0,34.4,34.1,33.6$, $30.4,29.1,28.3,26.5,23.5,22.6,20.6,17.6,17.5,15.8,14.4,12.6,11.7,11.5,7.6,6.5$ ppm; FTIR (KBr tablet): 3505 (m), 3424 (br, m), 3359 (m), 3057 (w), 2965 (s), 2931 (s), 2876 (s), 1711 (br, s), 1709 (br, s), 1659 (s), 1602 (m), 1524 (s), 1512 (s), 1466 (s), 1456 (s), 1440 (s), 1402 (s) $\mathrm{cm}^{-1}$; ESI MS (m/z): [M+Na] $]^{+}$Calcd for $\mathrm{C}_{50} \mathrm{H}_{76} \mathrm{FNNaO}_{10}$ 893; Found 893.

\subsubsection{Propargyl amide of C20-oxo-salinomycin 14}

Yield: $600 \mathrm{mg}, 72 \%$. Isolated as a white amorphous solid, $>95 \%$ pure by NMR and a single spot by TLC; $\mathrm{R}_{f}: 0.60$ in $50 \%$ EtOAc/n-hexane. UV-active and strains green with PMA; ${ }^{1} \mathrm{H}$ NMR (403 MHz, $\left.\mathrm{CD}_{2} \mathrm{Cl}_{2}\right) \delta 7.29(\mathrm{~d}, J=10.8 \mathrm{~Hz}, 1 \mathrm{H}), 7.19-7.08(\mathrm{~m}, 1 \mathrm{H}), 6.20(\mathrm{~d}, J=10.7$ Hz, 1H), 4.27 (ddd, $J=17.6,6.3,2.5 \mathrm{~Hz}, 1 \mathrm{H}$ ), 4.03 (ddd, $J=17.7,5.0,2.5 \mathrm{~Hz}, 1 \mathrm{H}$ ), 3.97-3.84 
(m, 2H), $3.81(\mathrm{q}, J=6.9 \mathrm{~Hz}, 1 \mathrm{H}), 3.76-3.65(\mathrm{~m}, 2 \mathrm{H}), 3.62(\mathrm{dd}, J=9.8,2.0 \mathrm{~Hz}, 1 \mathrm{H}), 3.39-3.28$ (m, 1H), $3.20(\mathrm{~d}, J=3.8 \mathrm{~Hz}, 1 \mathrm{H}), 2.85-2.66(\mathrm{~m}, 2 \mathrm{H}), 2.62$ (dt, $J=8.8,3.0 \mathrm{~Hz}, 1 \mathrm{H}), 2.58-2.47$ (m, 1H), 2.17 (t, $J=2.5 \mathrm{~Hz}, 1 \mathrm{H}), 2.07-0.53(\mathrm{~m}, 53 \mathrm{H}) \mathrm{ppm} ;{ }^{13} \mathrm{C} \mathrm{NMR}\left(101 \mathrm{MHz}, \mathrm{CD}_{2} \mathrm{Cl}_{2}\right) \delta$ 214.1, 190.0, 175.1, 143.6, 128.4, 106.4, 97.8, 89.7, 81.8, 79.7, 78.2, 75.5, 73.3, 71.7, 71.2, 70.2, $70.1,54.3,48.4,46.3,40.1,38.6,36.8,35.0,34.4,33.2,30.8,29.4,28.8,26.9,24.9,23.0,20.9$, 20.5, 17.3, 17.1, 15.9, 14.7, 14.6, 13.6, 11.8, 11.4, 8.0, 6.9 ppm, one signal overlapped; FT-IR (KBr tablet): 3472 (m), 3430 (br, m), 3338 (m), 3319 (m), 2966 (s), 2934 (s), 2878 (s), 2128 (w), 1703 (br, s), 1653 (s), 1531 (s), 1460 (s), 1443 (m), 1437 (m) cm¹; ESI MS (m/z): [M+Na $]^{+}$ Calcd for $\mathrm{C}_{45} \mathrm{H}_{71} \mathrm{NNaO}_{10} 808$; Found 808 .

\subsubsection{General procedure for preparation of novel conjugates of C20-oxo-salinomycin with} hydroxamic acids (analogues 11 and 12)

To a stirred solution of C20-oxo-salinomycin 10 (1.0 equiv.) in anhydrous $\mathrm{CH}_{2} \mathrm{Cl}_{2}$ at room temperature, 1,3-dicyclohexylcarbodiimide (2.0 equiv.) and an excess of 4dimethylaminopyridine were added, followed by addition of the corresponding hydroxamic acid (5.0 equiv.) in one portion. The resulting pale yellow solution was stirred for 24 hours, and then the organic solvents were evaporated under reduced pressure to dryness. The yellow residue was re-suspended in $\mathrm{CH}_{2} \mathrm{Cl}_{2}$ and filtered to remove the 1,3-dicyclohexylurea by-product. The filtrate was evaporated under reduced pressure and purified on silica gel using the CombiFlash system (EtOAc/n-hexane) to give the pure products of the reaction for 11 and $\mathbf{1 2}(26-31 \%$ yield) as clear oils. After 3-times repeated evaporation with $n$-pentane the oils were transformed to white amorphous solids. 


\subsubsection{Benzhydroxamic acid conjugate of C20-oxo-salinomycin 11}

Yield: $323 \mathrm{mg}, 31 \%$. Isolated as a white amorphous solid, $>95 \%$ pure by NMR and a single spot by TLC; $\mathrm{R}_{f}: 0.78$ in 50\% EtOAc/n-hexane. UV-active and strains green with PMA; ${ }^{1} \mathrm{H}$ NMR (401 MHz, $\mathrm{CD}_{2} \mathrm{Cl}_{2}$ ) $\delta 11.05(\mathrm{~s}, 1 \mathrm{H}), 8.19-8.05(\mathrm{~m}, 2 \mathrm{H}), 7.59-7.49$ (m, 1H), 7.48-7.38 (m, 2H), $7.23(\mathrm{~d}, J=10.8 \mathrm{~Hz}, 1 \mathrm{H}), 6.20(\mathrm{~d}, J=10.8 \mathrm{~Hz}, 1 \mathrm{H}), 4.05-3.91(\mathrm{~m}, 2 \mathrm{H}), 3.84-3.74(\mathrm{~m}$, 2H), $3.69(\mathrm{dd}, J=9.7,1.9 \mathrm{~Hz}, 1 \mathrm{H}), 3.30(\mathrm{dd}, J=11.5,2.3 \mathrm{~Hz}, 1 \mathrm{H}), 3.15$ (ddd, $J=11.0,8.7,6.1$ $\mathrm{Hz}, 1 \mathrm{H}), 2.94-2.82(\mathrm{~m}, 2 \mathrm{H}), 2.64-2.51(\mathrm{~m}, 2 \mathrm{H}), 2.38(\mathrm{~d}, J=5.3 \mathrm{~Hz}, 1 \mathrm{H}), 2.04-1.96(\mathrm{~m}, 1 \mathrm{H})$, 1.95-0.50 (m, 52H) ppm; ${ }^{13} \mathrm{C}$ NMR (101 MHz, $\left.\mathrm{CD}_{2} \mathrm{Cl}_{2}\right) \delta$ 216.6, 189.3, 173.9, 165.6, 142.5, $132.4,131.6,128.7,128.5,128.3,105.9,97.9,90.2,80.4,76.8,75.0,72.8,72.7,70.9,69.5,54.1$, $46.9,46.7,40.2,38.3,36.5,34.6,33.0,32.7,31.3,29.9,28.7,26.8,25.4,23.5,21.3,20.3,17.1$, 16.6, 15.9, 14.9, 14.5, 14.2, 11.9, 11.2, 7.8, 6.8 ppm; FT-IR (KBr tablet): $3570(\mathrm{~m}), 3501$ (br, m), 3321 (br, m), 3064 (m), 2965 (s), 2938 (s), 2879 (s), 1781 (s), 1702 (br, s), 1637 (m), 1602 (m), $1583(\mathrm{~m}), 1542(\mathrm{~m}), 1502$ (m), 1462 (s), 1446 (s), cm ${ }^{-1}$; ESI MS (m/z): [M+Na $]^{+}$Calcd for $\mathrm{C}_{49} \mathrm{H}_{73} \mathrm{NNaO}_{12} 891$; Found 891.

\subsubsection{Salicylhydroxamic acid conjugate of C20-oxo-salinomycin 12}

Yield: $130 \mathrm{mg}, 26 \%$. Isolated as a white amorphous solid, $>95 \%$ pure by NMR and a single spot by TLC; $\mathrm{R}_{f}: 0.35$ in 50\% EtOAc/n-hexane. UV-active and strains green with PMA; ${ }^{1} \mathrm{H}$ NMR (401 MHz, $\left.\mathrm{CD}_{2} \mathrm{Cl}_{2}\right) \delta 11.71(\mathrm{~s}, 1 \mathrm{H}), 11.25(\mathrm{~s}, 1 \mathrm{H}), 8.25(\mathrm{dd}, J=8.0,1.4 \mathrm{~Hz}, 1 \mathrm{H}), 7.43$ (ddd, $J=8.6,7.3,1.5 \mathrm{~Hz}, 1 \mathrm{H}), 7.26(\mathrm{~d}, J=10.8 \mathrm{~Hz}, 1 \mathrm{H}), 6.95(\mathrm{dd}, J=8.4,1.0 \mathrm{~Hz}, 1 \mathrm{H}), 6.90-$ $6.83(\mathrm{~m}, 1 \mathrm{H}), 6.22(\mathrm{~d}, J=10.8 \mathrm{~Hz}, 1 \mathrm{H}), 4.06-3.97(\mathrm{~m}, 2 \mathrm{H}), 3.86(\mathrm{dd}, J=10.1,2.8 \mathrm{~Hz}, 1 \mathrm{H}), 3.77$ $(\mathrm{q}, J=6.9 \mathrm{~Hz}, 1 \mathrm{H}), 3.71(\mathrm{dd}, J=9.6,1.9 \mathrm{~Hz}, 1 \mathrm{H}), 3.30(\mathrm{dd}, J=11.6,2.3 \mathrm{~Hz}, 1 \mathrm{H}), 3.18(\mathrm{ddd}, J=$ 11.0, 7.7, $6.9 \mathrm{~Hz}, 1 \mathrm{H}), 2.90(\mathrm{dq}, J=9.5,7.4 \mathrm{~Hz}, 2 \mathrm{H}), 2.66$ (dt, $J=9.1,2.4 \mathrm{~Hz}, 1 \mathrm{H}), 2.64-2.51$ 
(m, $1 \mathrm{H}), 2.40(\mathrm{~d}, J=5.7 \mathrm{~Hz}, 1 \mathrm{H}), 2.10-0.50(\mathrm{~m}, 53 \mathrm{H}) \mathrm{ppm} ;{ }^{13} \mathrm{C} \mathrm{NMR}\left(101 \mathrm{MHz}, \mathrm{CD}_{2} \mathrm{Cl}_{2}\right) \delta$ 217.2, 189.4, 173.8, 169.0, 162.1, 142.7, 135.2, 128.8, 127.9, 119.2, 118.5, 112.4, 106.1, 98.1, $90.6,80.6,77.0,75.2,73.2,72.9,71.1,69.6,54.2,47.0,46.7,40.4,38.5,36.7,34.9,33.0,32.9$, $31.4,30.1,28.8,27.0,25.9,23.7,21.7,20.5,17.4,16.6,16.1,15.2,14.60,14.58,12.0,11.4,8.0$, 7.0 ppm; FT-IR (KBr tablet): 3567 (br, m), 3301 (m), 2967 (s), 2939 (s), 2880 (s), 1788 (s), 1702 (br, s), 1655 (s), 1610 (s), 1588 (m), 1508 (s), 1484 (s), 1461 (s), 1448 (s) $\mathrm{cm}^{-1}$; ESI MS (m/z): $[\mathrm{M}+\mathrm{Na}]^{+}$Calcd for $\mathrm{C}_{49} \mathrm{H}_{73} \mathrm{NNaO}_{13}$ 907; Found 907.

\subsubsection{General procedure for preparation of novel salinomycin C20-propargylamine $\mathbf{1 5}$}

Method A: To a stirred solution of ketone 14 (1.0 equiv.) in $\mathrm{MeOH}$ at room temperature, propargylamine (10.0 equiv.) was added, followed by addition of a small portion of acetic acid. The resulting yellow solution was stirred for 1 hour at room temperature prior to the addition of $\mathrm{CeCl}_{3} \cdot 7 \mathrm{H}_{2} \mathrm{O}$ (1.0 equiv.), followed by the dropwise addition of a solution of $\mathrm{NaBH}_{3} \mathrm{CN}$ (2.0 equiv.) in $\mathrm{MeOH}$ over 12 hours using a dropping funnel. Organic solvent was then evaporated to dryness under reduced pressure to give a yellow oil. The yellow residue was re-dissolved in $\mathrm{CH}_{2} \mathrm{Cl}_{2}$, and washed twice with an aqueous solution of $\mathrm{H}_{2} \mathrm{SO}_{4}(\mathrm{pH}=1.0)$ and finally with distilled water. The organic layer was separated, concentrated under reduced pressure and purified on silica gel using the CombiFlash system $\left(50 \% \mathrm{EtOAc} / \mathrm{CHCl}_{3}\right)$ to give the pure product 15 (64\% yield) as a colorless oil. After 3-times repeated evaporation with $n$-pentane the oil was transformed to a white amorphous solid.

Method B: A solution of amine 16 (1.0 equiv.), 1,3-dicyclohexylcarbodiimide (1.2 equiv.) and propargylamine (2.0 equiv.) in $\mathrm{CH}_{2} \mathrm{Cl}_{2}$ was mixed with 1-hydroxybenzotriazole hydrate ( 0.5 equiv.) in THF, and stirred at $0{ }^{\circ} \mathrm{C}$ for 1 hour. Then, the reaction mixture was stirred 
at room temperature for further 24 hours. Afterwards, the organic solvents were evaporated under reduced pressure to dryness. The yellow residue was re-suspended in $\mathrm{CH}_{2} \mathrm{Cl}_{2}$ and filtered to remove the 1,3-dicyclohexylurea by-product. The filtrate was evaporated under reduced pressure and purified on silica gel using the CombiFlash system $\left(50 \% \mathrm{EtOAc} / \mathrm{CHCl}_{3}\right)$ to give the pure product 15 (38\% yield) as a colorless oil. After 3-times repeated evaporation with $n$-pentane the oil was transformed to white amorphous solid.

\subsubsection{Propargyl amide of C20-propargylaminosalinomycin $\mathbf{1 5}$}

Yield: $230 \mathrm{mg}, 64 \%$. Isolated as a white amorphous solid, $>95 \%$ pure by NMR and a single spot by TLC; $\mathrm{R}_{f}: 0.41$ in 50\% EtOAc/ $n$-hexane. Strains green with PMA; ${ }^{1} \mathrm{H}$ NMR (400 $\left.\mathrm{MHz}, \mathrm{CD}_{2} \mathrm{Cl}_{2}\right) \delta 7.27(\mathrm{t}, J=5.5 \mathrm{~Hz}, 1 \mathrm{H}), 6.10(\mathrm{dd}, J=10.7,2.2 \mathrm{~Hz}, 1 \mathrm{H}), 5.95(\mathrm{dd}, J=10.7,1.6$ Hz, 1H), 4.37 (ddd, $J=17.6,5.9,2.5 \mathrm{~Hz}, 1 \mathrm{H}), 4.18$ (ddd, $J=17.6,5.3,2.5 \mathrm{~Hz}, 1 \mathrm{H}), 4.07$ (d, $J=$ $9.6 \mathrm{~Hz}, 1 \mathrm{H}), 3.93-3.85(\mathrm{~m}, 1 \mathrm{H}), 3.80(\mathrm{dd}, J=13.7,6.8 \mathrm{~Hz}, 1 \mathrm{H}), 3.68(\mathrm{ddd}, J=20.1,10.0,2.3$ Hz, 2H), 3.58 (dd, $J=11.8,2.2 \mathrm{~Hz}, 1 \mathrm{H}), 3.46$ (qd, $J=16.8,2.4 \mathrm{~Hz}, 2 \mathrm{H}), 3.19$ (t, $J=1.8 \mathrm{~Hz}, 1 \mathrm{H})$, 3.00-2.82 (m, 2H), 2.70-2.56 (m, 2H), 2.54-2.47 (m, 1H), 2.24 (ddd, J = 11.5, 8.2, 6.1 Hz, 2H), 2.14-2.03 (m, 2H), 1.92-0.54 (m, 53H) ppm; ${ }^{13} \mathrm{C}$ NMR (101 MHz, $\left.\mathrm{CD}_{2} \mathrm{Cl}_{2}\right) \delta$ 212.9, 175.3, 132.4, 119.9, 106.7, 98.7, 89.0, 82.8, 82.2, 79.5, 77.3, 75.7, 74.6, 71.3, 71.1, 71.0, 69.4, 69.0, $55.5,53.8,48.2,46.9,40.8,38.7,37.9,37.6,36.6,32.9,30.9,30.8,29.6,28.9,28.6,27.1,25.9$, $22.43,22.40,20.7,17.6,17.4,15.9,14.8,14.6,14.5,12.0,11.7,8.2,6.6$ ppm; FT-IR $(\mathrm{KBr}$ tablet): 3484 (s), 3434 (br, m), 3312 (s), 2963 (s), 2935 (s), 2877 (s), 1712 (s), 1668 (s), 1524 (s), 1459 (s), 1419 (m), 1403 (m) cm ${ }^{-1}$; ESI MS (m/z): $[\mathrm{M}+\mathrm{H}]^{+}$Calcd for $\mathrm{C}_{48} \mathrm{H}_{77} \mathrm{~N}_{2} \mathrm{O}_{9}$ 826; Found 826. 


\subsection{X-ray measurements}

X-ray data collection for colorless single crystals of 14 and 15 was performed on a fourcircle KUMA KM-4 diffractometer equipped with a two-dimensional CCD area detector. The graphite monochromatized $\operatorname{MoK} \alpha$ radiation $(\lambda=0.71973 \AA)$ and the $\omega$ scan technique $\left(\Delta \omega=1^{\circ}\right)$ were used for data collection. Data collection and reduction along with absorption correction were performed using CrysAlis software package [32]. The structure was solved by direct methods using the SHELXT program revealing positions of almost all non-hydrogen atoms. The remaining atoms were located from subsequent difference Fourier syntheses. The structure was refined using SHELXL-2014 [33] with the anisotropic thermal displacement parameters. The hydrogen atoms of the aromatic ring were refined with riding model. Visualization of the structures was made with the Diamond 3.0 program [34]. Details of the data collection parameters, crystallographic data and final agreement parameters are given in Table S1 (Supplementary Information). Hydrogen bonding geometry is collected in Table S2 (Supplementary Information).

\subsection{In vitro biological studies}

\subsubsection{Cell Culture}

Bloodstream form of $T$. brucei 427-221a [35] and human myeloid HL-60 cells [36] were in cultured in Baltz medium [37] supplemented with 16.7\% heat-inactivated bovine serum. All cultures were maintained at $37^{\circ} \mathrm{C}$ in a humidified atmosphere containing $5 \%$ carbon dioxide.

\subsubsection{Trypanocidal and cytotoxic assays}


Toxicity assays were performed as previously described [28,29]. In brief, trypanosomes and HL-60 cells were seeded at an initial cell density of $1 \times 10^{4} \mathrm{ml}^{-1}$ and $5 \times 10^{4} \mathrm{ml}^{-1}$, respectively, in 96-well plates in a final volume of $200 \mu \mathrm{l}$ of Baltz medium containing various concentrations of test compounds (tenfold dilutions from $100 \mu \mathrm{M}$ to $1 \mathrm{pM}$ ) and $0.9 \%$ DMSO. Wells containing only Baltz medium and 0.9\% DMSO served as controls. After $24 \mathrm{~h}$ incubation, $20 \mu 1$ of a $0.5 \mathrm{mM}$ resazurin solution prepared in PBS and sterile filtered was added. Incubation was continued for another $48 \mathrm{~h}$ and then the absorbance of the wells was read on a BioTek ELx808 microplate reader using a test wavelength of $570 \mathrm{~nm}$ and a reference wavelength of 630 $\mathrm{nm}$. The $\mathrm{GI}_{50}$ value (i.e. the concentration of a compound necessary to reduce the growth rate of cells by $50 \%$ compared to the control) was determined by linear interpolation according to the method described by Huber and Koella [38].

\subsubsection{Swelling experiments}

Changes in cell volume were measured by the light scattering methods as previously described [20]. Briefly, bloodstream forms of T. brucei were incubated at a cell density of $5 \times$ $10^{7}$ cells $\mathrm{ml}^{-1}$ in 96-well plates in a final volume of $200 \mu \mathrm{l}$ Baltz medium containing $100 \mu \mathrm{M}$ ionophore and $0.9 \%$ DMSO. Controls contained just $0.9 \%$ DMSO. Absorbance of the cultures was measured at $490 \mathrm{~nm}$ on a BioTEk ELx808 microplate reader every 10 min for an hour.

\section{Supporting Information}

The structures have been deposited with the Cambridge Crystallographic Data Center in the CIF format, no. CCDC 1879997 and 1879998 for $\mathbf{1 4}$ and 15, respectively. Copies of this information can be obtained free of charge from The Director, CCDC, 12 Union Road, 
Cambridge, CB2 1EZ, UK (fax: +44 1223336 033); E-mail: deposit@ccdc.cam.ac.uk or www: http://www.ccdc.cam.ac.uk.

Additional figures illustrating the mutual overlap of structures 13-15 from scXRD analysis as well as ${ }^{1} \mathrm{H},{ }^{13} \mathrm{C}$ and ${ }^{19} \mathrm{~F}$ NMR spectra of the newly synthesized compounds are available free of charge via Internet at http://xxx.

\section{Acknowledgments}

M.A. wishes to acknowledge the Polish Science Centre (NCN) for financial support by a SONATA grant (2016/23/D/ST5/00242) and the Foundation for Polish Science (FNP) for a START scholarship.

\section{References}

[1] M. Antoszczak, J. Rutkowski, A. Huczyński, Structure and biological activity of polyether ionophores and their semi-synthetic derivatives, in: G. Brahmachari (Ed.), Bioactive natural products. Chemistry and biology, Weinheim, 2015.

[2] M. Antoszczak, D. Steverding, A. Huczyński, Anti-parasitic activity of polyether ionophores, Eur. J. Med. Chem. 166 (2019) 32-47.

[3] H.D. Chapman, Rotation programmes for coccidiosis control, Int. Poult. Prod. 15 (2007) 7-9.

[4] V. Kaushik, J.S. Yakisich, A. Kumar, N. Azad, A.K.V. Iyer, Ionophores: Potential use as anticancer drugs and chemosensitizers, Cancers 10 (2018) 360.

[5] M. Antoszczak, A medicinal chemistry perspective on salinomycin as a potent anticancer and anti-CSCs agent, Eur. J. Med. Chem. 164 (2019) 366-377. 
[6] S. Zhou, F. Wang, E.T. Wong, E. Fonkem, T.-C. Hsieh, J.M. Wu, E. Wu, Salinomycin: A novel anti-cancer agent with known anti-coccidial activities, Curr. Med. Chem. 20 (2013) 4095-4101.

[7] C. Naujokat, R. Steinhart, Salinomycin as a drug for targeting human cancer stem cells, J. Biomed. Biotechnol. 2012 (2012) 950658.

[8] P.B. Gupta, T.T. Onder, G. Jiang, K. Tao, C. Kuperwasser, R.A. Weinberg, E.S. Lander, Identification of selective inhibitors of cancer stem cells by high-throughput screening, Cell 138 (2009) 645-659.

[9] S.V. Barrett, M.P. Barrett, Anti-sleeping sickness drugs and cancer chemotherapy, Parasitol. Today 16 (2000) 7-9.

[10] D. Steverding, Sleeping sickness and nagana disease caused by Trypanosoma brucei, in: C. Marcondes (Ed.) Arthropod Borne Diseases, Springer, Cham, 2017.

[11] J.R. Franco, P.P. Simarro, A. Diarra, J.G. Jannin, Epidemiology of human African trypanosomiasis, Clin. Epidemiol. 6 (2014) 257-275.

[12] A. Stich, P.M. Abel, S. Krishna, Human African trypanosomiasis, BMJ 325 (2002) 203206.

[13] G. Cecchi, R.C. Mattioli, J. Slingenbergh, S. De La Rocque, Land cover and tsetse fly distributions in sub-Saharan Africa, Med. Vet. Entomol. 22 (2008) 364-373.

[14] D. Malvy, F. Chappuis, Sleeping sickness, Clin. Microbiol. Infect. 17 (2011) 986-995.

[15] D. Steverding, The history of African trypanosomiasis, Parasit. Vectors 1 (2008) 3.

[16] World Health Organization - Trypanosomiasis, human African (sleeping sickness) [on-line access: 2019-02-18]. https://www.who.int/en/news-room/fact-sheets/detail/trypanosomiasishuman-afric an-(sleeping-sickness) 
[17] A.H. Fairlamb, Chemotherapy of human African trypanosomiasis: Current and future prospects, Trends Parasitol. 19 (2003) 488-494.

[18] E. Matovu, T. Seebeck, J.C. Enyaru, R. Kaminsky, Drug resistance in Trypanosoma brucei ssp., the causative agents of sleeping sickness in man and nagana in cattle, Microbes Infect. 3 (2001) 763-770.

[19] V. Delespaux, H.P. de Koning, Drugs and drug resistance in African trypanosomiasis, Drug Resist. Updat. 10 (2007) 30-50.

[20] D. Steverding, M. Antoszczak, A. Huczyński, In vitro activity of salinomycin and monensin derivatives against Trypanosoma brucei, Parasit. Vectors 9 (2016) 409.

[21] B. Li, J. Wu, W. Zhang, Z. Li, G. Chen, Q. Zhou, S. Wu, Synthesis and biological activity of salinomycin-hydroxamic acid conjugates, Bioorg. Med. Chem. Lett. 27 (2017) $1624-1626$.

[22] M. Antoszczak, K. Popiel, J. Stefańska, J. Wietrzyk, E. Maj, J. Janczak, G. Michalska, B. Brzezinski, A. Huczyński, Synthesis, cytotoxicity and antibacterial activity of new esters of polyether antibiotic - salinomycin, Eur. J. Med. Chem. 76 (2014) 435-444.

[23] M. Antoszczak, E. Maj, J. Stefańska, J. Wietrzyk, J. Janczak, B. Brzezinski, A. Huczyński, Synthesis, antiproliferative and antibacterial activity of new amides of salinomycin, Bioorg. Med. Chem. Lett. 24 (2014) 1724-1729.

[24] T.T. Mai, A. Hamaï, A. Hienzsch, T. Cañeque, S. Müller, J. Wicinski, O. Cabaud, C. Leroy, A. David, V. Acevedo, A. Ryo, C. Ginestier, D. Birnbaum, E. Charafe-Jauffret, P. Codogno, M. Mehrpour, R. Rodriguez, Salinomycin kills cancer stem cells by sequestering iron in lysosomes, Nat. Chem. 9 (2017) 1025-1033. 
[25] B. Borgström, X. Huang, M. Pošta, C. Hegardt, S. Oredsson, D. Strand, Synthetic modification of salinomycin: Selective $O$-acylation and biological evaluation, Chem. Commun. 49 (2013) 9944-9946.

[26] M. Antoszczak, A. Urbaniak, M. Delgado, E. Maj, B. Borgström, J. Wietrzyk, A. Huczyński, Y. Yuan, T.C. Chambers, D. Strand, Biological activity of doubly modified salinomycin analogs - Evaluation in vitro and ex vivo, Eur. J. Med. Chem. 156 (2018) $510-523$.

[27] A. Huczyński, M. Antoszczak, N. Kleczewska, M. Lewandowska, E. Maj, J. Stefańska, J. Wietrzyk, J. Janczak, L. Celewicz, Synthesis and biological activity of salinomycin conjugates with floxuridine, Eur. J. Med. Chem. 93 (2015) 33-41.

[28] D. Steverding, A. Huczyński, Trypanosoma brucei: Trypanocidal and cell swelling activities of lasalocid acid, Parasitol. Res. 116 (2017) 3229-3233.

[29] K. Merschjohann, F. Sporer, D. Steverding, M. Wink, In vitro effect of alkaloids on bloodstream forms of Trypanosoma brucei and T. congolense, Planta Med. 67 (2001) 623627.

[30] A. Huczyński, J. Janczak, J. Stefańska, M. Antoszczak, B. Brzezinski, Synthesis and antimicrobial activity of amide derivatives of polyether antibiotic - salinomycin, Bioorg. Med. Chem. Lett. 22 (2012) 4697-4702.

[31] N. Usachova, G. Leitis, A. Jirgensons, I. Kalvinsh, Synthesis of hydroxamic acids by activation of carboxylic acids with $N, N^{\prime}$-carbonyldiimidazole: Exploring the efficiency of the method, Synth. Commun. 40 (2010) 927-935.

[32] CrysAlis CCD and CrysAlis Red 1.171.38.43, Rigaku Oxford Diffraction, 2015.

[33] G.M. Sheldrick, Crystal structure refinement with SHELXL, Acta Cryst. C71 (2015) 3-8. 
[34] K. Brandenburg, K. Putz, Diamond, Ver. 3.0, Crystal and Molecular Structure Visualization, University of Bonn, Germany (2006).

[35] H. Hirumi, K. Hirumi, J.J. Doyle, G.A.M. Gross, In vitro cloning of animal infective bloodstream forms of Trypanosoma brucei, Parasitology 80 (1980) 371-382.

[36] S.J. Collins, R.C. Gallo, R.E. Gallagher, Continues growth and differentiation of human myeloid leukaemic cells in suspension cultures, Nature 270 (1977) 347-349.

[37] T. Baltz, D. Baltz, C. Giroud, L. Crockett L. Cultivation in a semi-defined medium of animal infective forms of Trypanosoma brucei, T. equiperdum, T. evansi, T. rhodesiense and T. gambiense, EMBO J. 4 (1985) 1273-1277.

[38] W. Huber, J.C. Koella, A comparison of three methods of estimating $\mathrm{EC}_{50}$ in studies of drug resistance of malaria parasites, Acta Trop. 55 (1993) 257-261. 